\title{
Development of Standardized Online Test to Assess the Students 21st Century Skills
}

\author{
Setiya Utari ${ }^{1}$, Jessie Manopo $^{2}$, Selly Feranie ${ }^{3}$, Eka Cahya Prima ${ }^{4}$, Bambang Heru Iswanto ${ }^{5}$ \\ \{su@upi.edu ${ }^{1}$, jessiemanopo@upi.edu², ekacahyaprima@upi.edu $\left.{ }^{4}\right\}$ \\ Department of Physics Education, Faculty of Mathematics and Science Education, Universitas \\ Pendidikan Indonesia, Bandung, Indonesia ${ }^{1,2,3}$
}

\begin{abstract}
Century Skills are such essential skills to be prepared for professionalism needed nowadays. Therefore, education curricula were more emphasizing to exercise these skills. To achieve this objective, we have to build a standard assessment test to make sure that students have accomplished these skills. This research attempted developing a set of 21st-century skills tests tested to some teachers in Jawa Barat with a sample of 45 teachers. The problems presented refer to the design standardized by the National Assessment of Educational Progress (NAEP). The test consisted of 10 concept comprehension questions and 1621 st-century skills problems with the rubric developed by Suzie Boss. The test was designed using Edmodo and Moodle platforms. The research result showed that the concept comprehension test has high validity, 0.628. As the 21 st-century skills test, there are some problems not validated. Therefore, some issues on this proposed standard test should be further improved.
\end{abstract}

Keywords: 21st-century Skills, Online Test

\section{Introduction}

21 st-century was marked by the rapid development of information and communications technology (ICT). Later, this has an impact on the professionalism needed towards the new competence that should be owned, like having extensive knowledge, mobility and collaborating skills, thinking skills, and the ability to communicate effectively [1, 2].

By the 21st-century challenge, the education world is required to be capable of preparing the human resource with some skills or a new suitable competence. Those essential skills are called the 21 st-century skills including thinking skills, working skills, using equipment skills, and some other skills that necessary so we can live in harmony as a good citizen of the world [3]. On the other hand, The American Association of Colleges for Teacher Education (AACTE) and the Partnership for 21 st Century Skills emphasize the necessary of critical and creative thinking, communicating, and collaborating skills, as well as technology literacy for citizens [4]. In 1996, UNESCO analyzed the demands of the working world and revealed the four pillars that should be developed in the education world, which are learning to know, learning to do, learning to live together, and learning to be. Since then, the education in the world aimed at the development of 21 st-century skills based on the four pillars as mentioned before.

On the other hand, the development of information and communications technology has been used intensively in the field of education. This technology is now playing an important role both in improving management and in the learning process. Some research results showed 
that the use of ICT in the education world had been enhanced students' skills including thinking, communicating, and collaborating skill [5]. On the higher-level education, the learning process that using ICT able to improve 21st-century skills [6]. While a study of computer-based assessment on elementary and secondary level education showed the ease of giving feedback, more effective and more accurate for the learning process, a problem that can be researched is how to assess the improvement of learner competency that is more complex [7].

Within the 21st-century skills framework, The National Education Association (NEA) stated that the skills of thinking, communicating, and collaborating related to the ability to solve a problem (problem-solving) [8]. Referring to this framework, it is clear that the assessment of a particular skill is a very complex activity. Therefore the development of assessment instruments requires intensive research to obtain contextual problems as topics to be solved through problem-solving laboratories [9]. This approach refers to the model of problem-solving laboratory (PSL) developed by Heller \& Heller [10]. Thus the 21 st-century skills testing can be done by developing an interactive test based on problem-solving.

One of the interactive test-based 21st-Century Skills testing instruments has been developed by the National Assessment of Educational Progress (NAEP) [11]. However, this test instrument is still under development. Therefore the research on the development of interactive 21stCentury Skills tests is still very open, especially for the development of 21st-Century Skills test in Indonesia. One obstacle is the need to describe real phenomena and complete data as material to solve the problem.

The Indonesian University of Education Elementary Physics Laboratory has developed several problem-based experiment modules that refer to the Heller \& Heller PSL model [12]. Besides, they also have developed an assessment instrument of 21 st Century Skills on Temperature and Heat topic, which is developed based on the framework of 21 st Century Skills. The testing of this instrument has a validity of 0.7 and a reliability of 0.82 [13]. Therefore, this PSL-based 21st Century Skill instrument can be used as a material for the development of an online-based 21st Century Skill interactive test instrument.

The development of online interactive test instruments is significant because it will facilitate the processing of test results more quickly. In addition to facilitating the provision of interactive tests, the content of this instrument can also be used to assess other skills. Furthermore, interactive tests can be developed to be a computer-based instrument of national examinations individually to evaluate the 21 st-Century Skills for high school students.

Concerning the 21 st Century Skills' framework, the Partnership of 21st-Century Skills (P21) revealed essential skills that needed to be equipped including (1) learning and innovation skills; (2) information, media, and technology skills; and (3) life and career skills. This framework is a support system that embodies standards of assessment, curriculum, and learning [4]. A comparison of the 21st Century Skills framework is shown in Table 1.

Whereas based on the National Education Association (NEA) (2012) the 21st Century Skills domain covers several aspects of critical thinking and problem solving related to giving reasons effectively, making decisions and solving problems [8]. Innovative and creative thinking covers the use of various techniques to get an idea of solving problems, applying creative ideas to achieve a real and useful contribution to the field where the innovation is implemented. Communicate effectively such as: using various types of media and technology, and knowing how to determine their effectiveness as assessing the effect, expressing useful thoughts and ideas using verbal, written, and non-verbal communication skills in various forms and contexts. Work in teams such as: working effectively and systematically in a diverse team, training flexibility and awareness to be involved in achieving goals, appreciating the contribution of each group member. 
Boss has developed several 21st-Century Skills domains from what has been developed by the National Education Association (NEA) [14]. However, the indicators developed by Boss are still comprehensive and from all aspects that might appear in the learning process, for this reason, we have a more straightforward point of indicators that is most likely to emerge through the learning process. Therefore we adopted and adapted the rubric that was built by Boss [15]. Table 2 is the rubric developed by Boss.

Table 1. 21st Century Skills Framework presented by some international organizations.

\begin{tabular}{lll}
\hline \multicolumn{1}{c}{ P21 (skills set) } & OECD (dimension) & \multicolumn{1}{c}{ ATC (Category) } \\
\hline Learning and innovation skills & Communication & Way of thinking \\
& Way of working \\
$\begin{array}{l}\text { Information, media and technology } \\
\text { skills }\end{array}$ & Information & Tools for working \\
Life and career skills & Ethics and social impact & Living in the word \\
\hline
\end{tabular}

Table 2. Development of instruments adopted and adapted from BIE.

\begin{tabular}{|c|c|c|c|c|}
\hline $\begin{array}{l}\text { PjBL vs. 4C } \\
\text { Steps }\end{array}$ & Critical Thinking & Collaboration & Communication & $\begin{array}{l}\text { Creative and } \\
\text { Innovative Thinking }\end{array}$ \\
\hline $\begin{array}{l}\text { Launching the } \\
\text { project }\end{array}$ & $\begin{array}{l}\text { Determine the } \\
\text { steps to solve the } \\
\text { problem. }\end{array}$ & $\begin{array}{l}\text { Distribute the task } \\
\text { given to the } \\
\text { members of the } \\
\text { group according to } \\
\text { problem-solving } \\
\text { steps }\end{array}$ & $\begin{array}{l}\text { Finding information } \\
\text { to gain the } \\
\text { knowledge needed } \\
\text { and sharing it to the } \\
\text { members of the } \\
\text { group }\end{array}$ & $\begin{array}{l}\text { Developing ideas to } \\
\text { improve the stages of } \\
\text { problem-solving }\end{array}$ \\
\hline $\begin{array}{l}\text { Building } \\
\text { knowledge and } \\
\text { understanding } \\
\text { and skills }\end{array}$ & $\begin{array}{l}\text { Ensuring effective } \\
\text { and efficient steps } \\
\text { to be used as } \\
\text { project completion }\end{array}$ & $\begin{array}{l}\text { Work in a reliable } \\
\text { team to complete } \\
\text { the project }\end{array}$ & $\begin{array}{l}\text { Write down } \\
\text { observations } \\
\text { effectively and } \\
\text { correctly }\end{array}$ & $\begin{array}{l}\text { Use the right methods } \\
\text { and techniques when } \\
\text { taking measurements. }\end{array}$ \\
\hline $\begin{array}{l}\text { Developing and } \\
\text { revising ideas } \\
\text { and products }\end{array}$ & $\begin{array}{l}\text { Criticize results, } \\
\text { and give reasons } \\
\text { scientifically based } \\
\text { on data collected }\end{array}$ & $\begin{array}{l}\text { Discuss with the } \\
\text { team to observe } \\
\text { results and express } \\
\text { opinions to } \\
\text { improve outcomes }\end{array}$ & $\begin{array}{l}\text { Communicate with } \\
\text { the team to provide } \\
\text { an explanation or } \\
\text { express ideas }\end{array}$ & $\begin{array}{l}\text { Express ideas to } \\
\text { improve results }\end{array}$ \\
\hline $\begin{array}{l}\text { Presenting } \\
\text { products and } \\
\text { answers to the } \\
\text { driving question }\end{array}$ & $\begin{array}{l}\text { Express the } \\
\text { limitations of the } \\
\text { results (product } \\
\text { strengths and } \\
\text { weaknesses) }\end{array}$ & $\begin{array}{l}\text { Playing a role in } \\
\text { drawing } \\
\text { conclusions and } \\
\text { agreeing on } \\
\text { findings produced } \\
\text { together }\end{array}$ & $\begin{array}{l}\text { Each group member } \\
\text { giving notes to the } \\
\text { results }\end{array}$ & $\begin{array}{l}\text { Expressing results in } \\
\text { creative ways }\end{array}$ \\
\hline
\end{tabular}

\section{Research Method}

Because this study aims to obtain an idea of the 21st-Century Skills' test items, several steps that need to be carried out in this study are capturing the 21st-Century Skills' framework based on expert validity analysis, developing a blueprint test based on the physics material in school curriculum, analyzing 21 st-Century Skills' assessment items based on the data collected. The built of the framework is done through a literature review (several 21st-Century Skills' Framework, a study of physics material in the 2013 Indonesian curriculum, and analyzing the 
contextual problems as project problems that can be developed) based on the adaptation of the frameworks from Suzie Boss that are tailored to the learning process that exercise the 21 stCentury Skills.

Content validity testing can be done by comparing the contents of the instrument with the subject matter being taught. The instrument was validated by three experts; then the validity was processed using the Content Validity Ratio (CVR) and Content Validity Index (CVI). The CVR and CVI values that have been obtained are then categorized based on the categories proposed by Lawshe (1975) [16].

Limited stage testing is conducted to determine the empirical validity and reliability of items, level of difficulty, and discriminating power. The test was tested to 45 high school physics teachers in West Java who came from several cities and districts. The item validity test was tested with Pearson product-moment correlation techniques. To find out the overall reliability of the questions it is necessary to analyze the items used the Cronbach's Alpha formula [17].

A good question is a question that is not too easy or too difficult. Difficulty index is a number that indicates the difficulty of a problem. The difficulty index is between 0 (difficult) to 1 (easy), the difficulty index is a comparison value of students who answered correctly to the number of students who took the test [17].

Discriminating power is a measurement of a test item, whether is it able to distinguish students who have mastered competence from students who have not/lack learned the competency or not. According to Zainal Arifin, iscriminating power calculated using the formula for the discriminating power of test items (2014).

\section{Result and Discussion}

The developed online test model refers to the test model developed by the NAEP. In the first section, there are ten types of multiple-choice tests to assess the mastery of related physics concepts. Some articles need to be given whose function is to recall the related physics concepts and giving motivations related to the application of the related contextual concepts. In section two, multiple-choice tests are carried totaling 16 questions that assess the 21st-Century Skills based on the rubric developed by Boss (2012) [14]. Framework analysis is based on the validity calculation method developed by five experts, with the calculation of CVR and CVI are shown in Table 3.

Based on the CVR calculation, test items that were developed are in the category useful but not essential and essential. On the other hand, CVI calculated are in the helpful category but not necessary. Thus the questions used are feasible to measure conceptual mastery. The results of an expert's examination of the 21st-Century Skills' issues are shown in Table 4.

Based on the CVR calculation, the questions that were developed in the category not necessary, useful but not essential and essential. On the other hand, CVI is in the category very crucial. Thus the questions used are suitable to test students' 21st-Century Skills. The results of the limited stage testing were conducted on 45 teachers in the area of West Java. The validity and reliability tests were obtained from the data revealed, as seen in Table 5.

Table 3. Results of Analysis Frameworks on The Concept Comprehension Test.

\begin{tabular}{lllll}
\hline No & Concept Comprehension Aspects & Description of Validation Results & CVR & CVI \\
\hline 1 & $\begin{array}{l}\text { Use the correct representation to explain a } \\
\text { concept }\end{array}$ & 1 & 0,64
\end{tabular}




\begin{tabular}{|c|c|c|c|c|}
\hline No & Concept Comprehension Aspects & Description of Validation Results & CVR & CVI \\
\hline 2 & Apply suitable scientific knowledge & $\begin{array}{l}\text { The phenomenon is equipped } \\
\text { with a picture explanation }\end{array}$ & 0,6 & \\
\hline 3 & $\begin{array}{l}\text { Identify the use of concepts to produce } \\
\text { precise models }\end{array}$ & & 1 & \\
\hline 4 & Make the right prediction & & 1 & \\
\hline 5 & Identify data/evidence related to the concept & $\begin{array}{l}\text { Figures } 2 \text { and } 3 \text { have to be improved } \\
\text { with the volume geometry of } \\
\text { different objects. }\end{array}$ & 0,6 & \\
\hline 6 & $\begin{array}{l}\text { Apply conceptual knowledge to solve } \\
\text { problems }\end{array}$ & & 1 & \\
\hline 7 & $\begin{array}{l}\text { Expressways to explore phenomena based on } \\
\text { concepts }\end{array}$ & $\begin{array}{l}\text { Make the image clear with the real } \\
\text { aerometer (photo) }\end{array}$ & 0,6 & \\
\hline 8 & $\begin{array}{l}\text { Identify phenomena to explain facts based on } \\
\text { concepts }\end{array}$ & & 1 & \\
\hline 9 & $\begin{array}{l}\text { Apply the concept to predict the process that } \\
\text { will happen }\end{array}$ & & 1 & \\
\hline 10 & $\begin{array}{l}\text { Analyze and interpret data to make the } \\
\text { right decision }\end{array}$ & $\begin{array}{l}\text { Facts given equipped with the image, } \\
\text { so it's easier not too abstract }\end{array}$ & 0,6 & \\
\hline
\end{tabular}

Based on the research results, the questions related to the application of the concept have sufficient and high validity criteria, they have good discriminating power and have a moderate level of difficulty, but adequate reliability. Based on the limited test phase 1, only $40 \%$ of the remaining questions that acceptable, need to be improved, concerning their validity, discriminating power and difficulty level. Issues related to expressing representations in other forms, expressing the results of observations, using knowledge to predict, exploring, and using concepts to explain a phenomenon have not been validated well, problems cannot distinguish several medium and talented students.

Regarding 21st-Century Skills' questions for critical thinking skills, all items have been validated well; it means that things can be used to assess critical thinking skills. However, the reliability is very low, and it means that the problems cannot be used as an assessment, this inconsistency arose due to the diverse characteristics of the sample. The issues have a difficulty level of medium and high. Several questions involving thinking skills related to critical thinking of procedures/steps, critiquing the results, being able to express the limitations of the results, investigation of this experience is not possessed by test takers, so the test is seen as challenging. Most of the questions cannot distinguish between smart and less talented students. In addition to the sample characteristics, with different teacher experiences, there is a possibility that teachers who only guess can answer the questions correctly.

Regarding collaboration skills questions, most have been validated well, can distinguish and have comfortable and moderate levels of difficulty, with low reliability. Although we realize that these skills are still challenging to assess with multiple-choice tests, what is measured may be more like collaborative knowledge and an attitude to collaborate, so that some questions are relatively straightforward. However, problems related to revealing the results of limitations that need to be discussed are somewhat tricky.

Table 4. Results of Analysis of the 21st-Century Skills Test Framework.

\begin{tabular}{lllll}
\hline No & Indicator & Comment & CRV & CVI \\
\hline Cr1 & Determine the steps of problem-solving & $\begin{array}{l}\text { The video for making an aerometer is } \\
\text { unclear to show the wrong part }\end{array}$ & 0,6 & 0.8
\end{tabular}




\begin{tabular}{|c|c|c|c|c|}
\hline No & Indicator & Comment & CRV & CVI \\
\hline $\mathrm{Cr} 2$ & $\begin{array}{l}\text { Ensuring effective and efficient steps to be } \\
\text { used as project completion }\end{array}$ & - & 1 & \\
\hline $\mathrm{Cr} 3$ & $\begin{array}{l}\text { Criticize results and give reasons scientifically } \\
\text { based on data }\end{array}$ & - & 1 & \\
\hline $\mathrm{Cr} 4$ & $\begin{array}{l}\text { Express the limitations of the results (product } \\
\text { strengths and weaknesses) }\end{array}$ & $\begin{array}{l}\text { The picture was improved by showing a } \\
\text { comparison of the same measurement }\end{array}$ & 0,6 & \\
\hline Col1 & $\begin{array}{l}\text { Distribute the task given to the members of the } \\
\text { group according to the steps of problem- } \\
\text { solving }\end{array}$ & & 1 & \\
\hline $\mathrm{Col} 2$ & Work in a reliable team to complete the project & - & 1 & \\
\hline $\mathrm{Col} 3$ & $\begin{array}{l}\text { Discuss with the team to observe results and } \\
\text { express ideas to improve outcomes }\end{array}$ & $\begin{array}{l}\text { The data shows things that have not } \\
\text { been achieved from the purpose of the } \\
\text { investigation }\end{array}$ & 0,2 & \\
\hline Col4 & $\begin{array}{l}\text { Playing a role in drawing conclusions and } \\
\text { agreeing on findings produced together }\end{array}$ & - & 1 & \\
\hline \multirow[t]{2}{*}{$\begin{array}{l}\text { Com } \\
1\end{array}$} & $\begin{array}{l}\text { Search for information to gain the knowledge } \\
\text { needed and present it to the group in the }\end{array}$ & Articles are given orally and in writing & 0,2 & \\
\hline & completion of the project & The article reading is too long & & \\
\hline $\begin{array}{l}\text { Com } \\
2\end{array}$ & $\begin{array}{l}\text { Write down observation results effectively and } \\
\text { correctly }\end{array}$ & - & 1 & \\
\hline $\begin{array}{l}\text { Com } \\
3\end{array}$ & $\begin{array}{l}\text { Communicate with the team to provide an } \\
\text { explanation or express ideas }\end{array}$ & $\begin{array}{l}\text { Data needs to be more precise and data } \\
\text { was incomplete }\end{array}$ & 0,6 & \\
\hline $\begin{array}{l}\text { Com } \\
4\end{array}$ & Each group member giving notes to the results & & 1 & \\
\hline Cre1 & $\begin{array}{l}\text { Express the idea improve the steps of problem- } \\
\text { solving }\end{array}$ & $\begin{array}{l}\text { Articles have to be given orally and in } \\
\text { writing. }\end{array}$ & 0,6 & \\
\hline Cre2 & $\begin{array}{l}\text { Use the right methods and techniques when } \\
\text { taking measurements. }\end{array}$ & 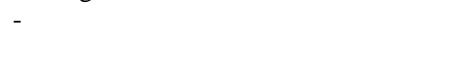 & 1 & \\
\hline Cre3 & Express ideas to improve results & - & 1 & \\
\hline Cre4 & Expressing results in creative ways & $\begin{array}{l}\text { Statement of the results of the } \\
\text { investigation needs to be improved (the } \\
\text { sentence in the questions is still } \\
\text { ambiguous) }\end{array}$ & 0,6 & \\
\hline
\end{tabular}

Note: $\mathrm{Cr}=$ Critical thinking skill; $\mathrm{Col}=$ collaborating skill; $\mathrm{Com}=$ communicating skill, $\mathrm{Cre}=$ Creative thinking skill.

Concerning the communicating skills questions, the questions related to determining the additional knowledge needed have not been validated well, the items need to be improved because participants' experience is different. It is a good idea to ask participants to determine the keywords needed to find additional information. Most of the questions cannot distinguish between smart and less talented students. This may be due to different teacher experiences, so testing needs to be applied to the actual sample.

Regarding creative thinking skills questions, some problems related to providing innovative ideas, to having a measurement, and plans to improve results have not been validated well. This can be due to the students don't have the experience in these, so the question needs to be improved. As for other thinking skills related to having the right tools and materials, the item needs to be improved, the problem and the purpose of the investigation need to be given, not just giving them meaning, so the question needs to be improved. 
Table 5. Characteristics of the limited test results.

\begin{tabular}{|c|c|c|c|c|c|}
\hline No & Val & Rel. & $\begin{array}{l}\text { Dis.Powe } \\
\mathrm{r}\end{array}$ & $\begin{array}{l}\text { Diff.inde } \\
\quad \mathrm{x}\end{array}$ & Explanation \\
\hline \multicolumn{6}{|c|}{ Concept comprehension test } \\
\hline 1 & 0,25 & 0,42 & 0,25 & 0,62 & $\begin{array}{l}\text { Low validity, moderate difficulty, enough discriminating } \\
\text { power. }\end{array}$ \\
\hline 2 & 0,52 & & 0,67 & 0,56 & $\begin{array}{l}\text { Enough validity, moderate difficulty, very high } \\
\text { discriminating power. }\end{array}$ \\
\hline 3 & 0,34 & & 0,42 & 0,36 & $\begin{array}{l}\text { Low validity, moderate difficulty, high discriminating } \\
\text { power. }\end{array}$ \\
\hline 4 & 0,39 & & 0,42 & 0,80 & Low validity, low difficulty, high discriminating power. \\
\hline 5 & 0,02 & & 0,00 & 0,38 & Low validity, moderate difficulty, low discriminating power. \\
\hline 6 & 0,55 & & 0,67 & 0,69 & $\begin{array}{l}\text { Enough validity, moderate difficulty, very high } \\
\text { discriminating power. }\end{array}$ \\
\hline 7 & 0,26 & & 0,33 & 0,73 & Low validity, low difficulty, enough discriminating power. \\
\hline 8 & 0,63 & & 0,50 & 0,84 & High validity, low difficulty, high discriminating power. \\
\hline 9 & 0,54 & & 0,58 & 0,56 & $\begin{array}{l}\text { Enough validity, moderate difficulty, high discriminating } \\
\text { power. }\end{array}$ \\
\hline 10 & 0,58 & & 0,75 & 0,38 & $\begin{array}{l}\text { Low validity, moderate difficulty, enough discriminating } \\
\text { power. }\end{array}$ \\
\hline \multicolumn{6}{|c|}{ 21st-Century Skills Test } \\
\hline 1 & 0,47 & 0,17 & 0,50 & 0,51 & $\begin{array}{l}\text { Enough validity, moderate difficulty, high discriminating } \\
\text { power. }\end{array}$ \\
\hline 2 & 0,45 & & 0,08 & 0,13 & Enough validity, high difficulty, low discriminating power. \\
\hline 3 & 0,43 & & 0,17 & 0,09 & Enough validity, high difficulty, low discriminating power. \\
\hline 4 & 0,46 & & 0,08 & 0,29 & $\begin{array}{l}\text { Enough validity, moderate difficulty, low discriminating } \\
\text { power. }\end{array}$ \\
\hline 5 & 0,63 & & 0,25 & 0,89 & High validity, low difficulty, enough discriminating power. \\
\hline 6 & 0,70 & & 0,67 & 0,80 & High validity, low difficulty, high discriminating power. \\
\hline 7 & 0,61 & & 0,42 & 0,29 & High validity, high difficulty, high discriminating power. \\
\hline 8 & 0,58 & & 0,58 & 0,49 & $\begin{array}{l}\text { Enough validity, moderate difficulty, high discriminating } \\
\text { power. }\end{array}$ \\
\hline 9 & 0,01 & & 0,00 & 0,04 & Low validity, high difficulty, low discriminating power. \\
\hline 10 & 0,47 & & 0,08 & 0,38 & $\begin{array}{l}\text { Enough validity, moderate difficulty, low discriminating } \\
\text { power. }\end{array}$ \\
\hline 11 & 0,47 & & 0,17 & 0,18 & Enough validity, high difficulty, low discriminating power. \\
\hline 12 & 0,54 & & 0,08 & 0,36 & $\begin{array}{l}\text { Enough validity, moderate difficulty, low discriminating } \\
\text { power. }\end{array}$ \\
\hline 13 & 0,72 & & 0,33 & 0,76 & High validity, low difficulty, enough discriminating power. \\
\hline 14 & 0,18 & & 0,08 & 0,02 & Low validity, high difficulty, low discriminating power. \\
\hline 15 & 0,38 & & 0,17 & 0,09 & Low validity, high difficulty, low discriminating power. \\
\hline 16 & 0,69 & & 0,50 & 0,24 & High validity, high difficulty, high discriminating power. \\
\hline
\end{tabular}

\section{Conclusion}

Frameworks and indicators of problems, issues related to concept comprehension and 21stcentury skills have been produced through judgment trials by five experts (in physics and physics education), for knowledge acquisition problems show CVR values are useful and essential and CVI is in the crucial category so that the test can be used. For issues related to 21 st-century skills, the original CVR is in the useful and essential category, and the CVI in the crucial group, so some questions still need improvement.

Limited stage testing shows that only $40 \%$ of the questions involving concept comprehension that can be used, the rest needs to be improved. On the other hand, the issues 
involving 21 st-century skills have a very low level of reliability. Some of the questions still need to be improved, especially in the problems related to the laboratory data.

\section{References}

[1] Dunning, J. H.: Regions, globalization, and the knowledge economy: the issues stated. Regions, globalization, and the knowledge-based economy, 7-41 (2000)

[2] Levy, F., \& Murnane, R. J.: The new division of labor: How computers are creating the next job market. Princeton University Press (2005)

[3] Griffin, P., \& Care, E. (Eds.).: Assessment and teaching of 21st-century skills: Methods and approach. Springer (2014)

[4] Greenhill, V.: 21st Century Knowledge and Skills in Educator Preparation. Partnership for 21stcentury skills (2010)

[5] Li, K. M.: Integrating Weblogs in A Pedagogy Model for Enhancing Students'critical Thinking Skills. Research and Practice in Technology-enhanced learning, 5(01), pp. 35-49 (2010)

[6] Pheeraphan, N.: Enhancement of the 21 st-century skills for Thai higher education by the integration of ICT in the classroom. Procedia-Social and Behavioral Sciences, 103, pp. 365-373 (2013)

[7] Shute, V. J., \& Rahimi, S.: Review of computer-based assessment for learning in elementary and secondary education. Journal of Computer Assisted Learning, 33(1), 1-19 (2017)

[8] National Education Association (NEA): Preparing 21st Century Students for a Global Society (2013)

[9] Wenning, C. J.: Assessing nature-of-science literacy as one component of scientific literacy. Journal of Physics Teacher Education Online, 3(4), pp. 3-14 (2006)

[10] Heller, P. \& Heller, K.: Problem-solving labs, in cooperative group problem-solving in physics. Research Report Departement of Physics University of Minnesota (1999)

[11] Bennett, R. E., Persky, H., Weiss, A. R., \& Jenkins, F.: Problem Solving in Technology-Rich Environments, A Report From the NAEP Technology-Based Assessment Project, Research and Development Series, National Center for Education Statistics Institute of Education Sciences U.S. Department of Education (2007)

[12] Prima, E. C., Utari, S., Chandra, D. T., Hasanah, L., \& Rusdiana, D.: Heat and temperature experiment designs to support students' conception on nature of science. JOTSE: Journal of technology and science education, 8(4), pp. 453-472 (2018)

[13] Prima, E. C., Karim, S., Utari, S., Ramdani, R., Putri, E. R. R., \& Darmawati, S. M.: Heat Transfer Lab Kit using Temperature Sensor based ArduinoTM for Educational Purpose. Procedia Engineering, 170, pp. 536-540 (2017)

[14] Boss, S., Larmer, J., \& Mergendoller, J. R.: PBL for 21st-century success: Teaching critical thinking, collaboration, communication, and creativity. Buck Institute for Education (2012)

[15] Utari, S. \& Supriyatin, T.: 21st-century skills profile of the first junior high school in the making project of ice cream on kalor topics and changes of substance., Proceedings of the 8th UPI-UPSI \& 2 nd ICES International Seminar (2018)

[16] Lawshe, C. H. A quantitative approach to content validity. Personal Psychology. 28 (4), pp. 563 575 (1975)

[17] Arikunto, S.: Dasar-dasar evaluasi pendidikan edisi 2. Jakarta: Bumi Aksara (2012) 